\title{
An in vitro procedure for studying enzymic dephosphorylation of phytate in maize-soyabean feeds for turkey poults
}

\author{
BY KRZYSZTOF ŻYEA*, DAVID R. LEDOUX, ANGEL GARCIA \\ AND TRYGVE L. VEUM \\ Department of Animal Sciences, University of Missouri, Columbia, MO 65211, USA
}

(Received 2 March 1994 -Revised 27 October 1994 - Accepted 14 November 1994)

\begin{abstract}
An in vitro method was developed to predict inorganic $\mathbf{P}$ release from maize-soyabean poultry feeds containing supplemental phytase $(E C 3.1 .3 .8)$, and to quantify the effect of acid phosphatase (EC 3.1.3.2), fungal protease $(E C$ 3.4.23.6) and Aspergillus niger cellulase $(E C$ 3.2.1.4) on phytate dephosphorylation. Pepsin (EC 3.4.23.1) and pancreatin digestion periods were preceded by a $30 \mathrm{~min}$ pre-incubation at pH 5.25 to simulate digestion in the crop of poultry. Pancreatin digestion was carried out in dialysis tubing, with a ratio of about $1: 25(\mathrm{v} / \mathrm{v})$ between the digesta and dialysing medium, to simulate gradient absorption from the duodenum. The feed:water ratio was kept within physiological limits and a constant proportion of feed weight to digestive enzymes was maintained. There was a linear response to increasing dosages of phytase up to 1000 phytase units (FTU)/kg feed, and to increasing phosphate concentration in feeds. In vivo validation was performed with growing turkeys (1-3 weeks) fed on diets containing $12 \mathrm{~g} \mathrm{Ca} / \mathrm{kg}$ and 0,500 or $1000 \mathrm{FTU}$ phytase/kg in a factorial arrangement with 0 , 1,2 or 3 g supplemental phosphate/ $\mathrm{kg}$ (from $\mathrm{KH}_{2} \mathrm{PO}_{4}$ ). After a simple transformation (variable/in vitro $P=f($ in vitro $\mathrm{P})$ ), amounts of $\mathrm{P}$ hydrolysed from feed samples by in vitro digestions correlated with 3-week body-weight gain $(R 0.986, P<0.0001)$, toe ash $(R 0.952, P<0.0001)$, feed intake $(R 0.994$, $P<0.0001)$ and feed efficiency $(R 0.992, P<0.0001)$. The dephosphorylating ability of phytase in vitro was significantly enhanced $(P<0.05)$ by the addition of acid phosphatase. Fungal acid protease and Aspergillus niger cellulase also enhanced the dephosphorylation process in vitro.
\end{abstract}

In vitro method: Feed dephosphorylation: Phytase: Turkey

Salts of phytic acid (myo-inositol hexakis-dihydrogenphosphate, phytate) comprise about two-thirds of the $P$ in cereal grains and oil seed meals, the two major components of poultry feeds. Phytate $\mathrm{P}$ is poorly available to single-stomached animals. Insoluble proteinmetal-phytate complexes are formed below the isoelectric $\mathrm{pH}$ of proteins, reducing $\mathrm{Ca}, \mathrm{Mg}$, $\mathrm{Fe}$ and $\mathrm{Zn}$ absorption from the intestinal tract of animals and humans (Reddy et al. 1989). Physiological $\mathrm{pH}$ values alter solubilities of phytate complexes with $\mathrm{Ca}, \mathrm{P}$ and protein (Champagne \& Phillippy, 1989) and influence the velocity of reactions catalysed by enzymes of digestive, feed or food origin. Phytate, and different myo-inositol phosphate esters, products of enzymic hydrolysis of phytate, vary in their inhibitory effect on pepsin (EC 3.4.23.1) and $\alpha$-amylases, and show different chelating capacities toward nutrients. As a result, the digestibility of protein, starch and lipid is reduced (Reddy et al. 1989).

Phytase, myo-inositol hexaphosphate phosphohydrolase (EC 3.1.3.8 and $E C$ 3.1.3.24) catalyses the stepwise hydrolysis of inorganic orthophosphate from the myo-inositol backbone of phytate (Irving \& Cosgrove, 1974). Phytase preparations derived from moulds and added to diets fed to single-stomached animals have improved retention of phytate $P$

\footnotetext{
* Present address: Department of Food Biotechnology, University of Agriculture, 29-Listopada Ave., 46; PL 31-425 Krakow, Poland.
} 
and $\mathrm{Ca}$, and decreased the content of $\mathrm{P}$ in animal manures (Nelson et al. 1971; Simons et al. 1990; Ketaren et al. 1993; Lei et al. 1993; von Schöner et al. 1993). Phytase added as a feed ingredient is subjected to the environmental conditions present in the intestinal tract (e.g. pH changes, proteolysis). In the intestine, phytase acts on complexes of phytate with other plant tissue components, which are parts of the complex matrix of digested food in the intestinal lumen. An assay involving standardized physiological conditions is therefore required for studying the action of an exogenous phytase on $P$ release from feeds.

Lease (1967) proposed an in vitro procedure, involving pepsin and pancreatin digestion, to determine availability of $\mathrm{Zn}$ in oilseed meals. The dialysability of ${ }^{65} \mathrm{Zn}$ from the $\mathrm{pH} 6.8$ pancreatin digest agreed poorly with the in vivo uptake of ${ }^{65} \mathrm{Zn}$ by tissues. An in vitro method simulating human digestion and absorption of non-haem dietary Fe from complex meals (Miller et al. 1981) generated results that correlated well with in vivo results from humans (Schricker et al. 1981). Wolters et al. (1993) used a continuous in vitro method based on a hollow-fibre dialysing unit for estimation of the bioavailability of minerals in foods. This procedure correlated well with the method of Miller et al. (1981) for $\mathrm{Zn}, \mathrm{Cu}$ and Fe estimation, but not for $\mathrm{Ca}$ and $\mathrm{Mg}$. Bedford \& Classen (1993) designed an in vitro assay for predicting the effects of xylanase $(E C 3.2 .1 .8)$ addition to rye-based feeds for poultry. The growth-promoting ability of a commercial xylanase preparation was related to in vitro viscosity of the diet, which underwent pepsin and pancreatin digestions.

A valid in vitro method for the prediction of $P$ availability in practical diets fed to turkeys does not exist. Thus, the purpose of this research was to design an in vitro method to determine $\mathbf{P}$ availability from maize-soyabean-meal feeds containing commercial phytase and to validate the procedure with an in vivo experiment with turkey poults. 'Available P' is used throughout this work to describe the sum of inorganic $P$ (endogenous or supplemental), organic non-phytate $P$, and a part of phytate $P$ which is available, or is made available, e.g. by enzymic release (Sanders et al. 1992). For the in vitro studies the term 'available $\mathbf{P}$ ' is synonymous with 'dialysable $\mathbf{P}$ ', i.e. inorganic $\mathbf{P}$ concentration in the dialysate, while for in vivo studies it refers to the ability to promote growth, or to increase the percentage of toe ash. Factors that may influence feed dephosphorylation (acid phosphatase and tissue-degrading activities, different $\mathrm{Ca}$ concentrations in the diet) were also tested in vitro.

\section{MATERIALS AND METHODS}

\section{Animals}

Two hundred and forty newly hatched ( $1 \mathrm{~d}$ old) Nicholas Large White turkey hens were obtained from a commercial hatchery (Cargill, Inc., California, MO, USA). Birds were housed in stainless steel battery brooders with wire-mesh floors, with temperature maintained at $32 \pm 1^{\circ}$ in the first week. Every $7 \mathrm{~d}$ the temperature was decreased by $2^{\circ}$. Lighting was continuous and feed and water were provided ad lib. On day 7, poults were weighed (mean weight $110 \mathrm{~g}$ ) and assigned randomly to dietary treatments. On day 21 , poults were weighed individually and feed consumption was determined per pen. The poults were then killed by asphyxiation with $\mathrm{CO}_{2}$ followed by cervical dislocation. Toe samples were obtained by carefully and uniformly severing the middle toe from each foot between the second and third tarsal bones.

\section{Diet composition and experimental design}

The composition of the diets is given in Table 1. Turkeys were fed on a starter maize-soyabean-meal diet that met or exceeded all nutrient requirements (National Research Council, 1984) for 1 week (diet NRC), and experimental diets for another 2 
Table 1. Composition and nutrient content of the basal diets $(\mathrm{g} / \mathrm{kg})$

\begin{tabular}{|c|c|c|}
\hline & Diet NRC & Diet $E$ \\
\hline \multicolumn{3}{|l|}{ Ingredients } \\
\hline Soyabean meal ( $440 \mathrm{~g}$ crude protein $/ \mathrm{kg}$ ) & $481 \cdot 18$ & 563.43 \\
\hline Maize (ground, shelled) & $405 \cdot 17$ & 341.98 \\
\hline Meat-and-bone meal & $60 \cdot 00$ & - \\
\hline Maize oil & $29 \cdot 65$ & $45 \cdot 22$ \\
\hline Dicalcium phosphate* & $9 \cdot 97$ & - \\
\hline Calcium carbonate $(380 \mathrm{~g} \mathrm{Ca} / \mathrm{kg})$ & $6 \cdot 29$ & $26 \cdot 15$ \\
\hline Salt $(\mathrm{NaCl})$ & $3 \cdot 00$ & 4.00 \\
\hline Methionine-hydroxy analogue & $2 \cdot 44$ & $2 \cdot 04$ \\
\hline Trace mineral premix $\dagger$ & $1 \cdot 00$ & 1.00 \\
\hline Selenium premix $\ddagger$ & $0 \cdot 50$ & 0.50 \\
\hline Vitamin premix $\S$ & 0.50 & 0.50 \\
\hline Choline-HCl & $0 \cdot 30$ & $0 \cdot 19$ \\
\hline Variable ingredients $\|$ & - & $15 \cdot 00$ \\
\hline \multicolumn{3}{|l|}{ Nutrient content } \\
\hline $\mathrm{Ca} \uparrow$ & $12 \cdot 0$ & $12 \cdot 0$ \\
\hline Available Pq & $6-0$ & 1.9 \\
\hline Total P & $8 \cdot 39$ & $4 \cdot 63$ \\
\hline Protein $\|$ & $280 \cdot 00$ & $280 \cdot 00$ \\
\hline Metabolizable energy $(\mathrm{MJ} / \mathrm{kg})$ & $11 \cdot 732$ & $11 \cdot 732$ \\
\hline Crude fat $\emptyset$ & $54 \cdot 1$ & $62 \cdot 7$ \\
\hline Fibreף & $4 \cdot 40$ & $4: 86$ \\
\hline
\end{tabular}

Diet NRC, basal diet providing nutrients at concentrations recommended by the National Research Council (1984); Diet $E$, diet containing all nutrients except $P$.

* Contained $185 \mathrm{~g} \mathrm{P} / \mathrm{kg}$ and $200 \mathrm{~g} \mathrm{Ca} / \mathrm{kg}$.

$\dagger$ Provided (mg/kg diet) $: \mathrm{MnO}_{2} 222, \mathrm{ZnO} 209, \mathrm{FeSO}_{4} .7 \mathrm{H}_{2} \mathrm{O} 654, \mathrm{Cu}_{2} \mathrm{O}$ 9, ethylenediamine dihydroiodide 1.9, $\mathrm{CaCO}_{3} 160$.

\$ Supplied $0.2 \mathrm{mg} \mathrm{Se} / \mathrm{kg}$ diet.

$\S$ Provided (mg/kg diet): all-trans-retinyl acetate 3.03 , cholecalciferol $96.4 \mu \mathrm{g}$, all-rac- $\alpha$-tocopheryl acetate 14 , niacin 55 , calcium pantothenate 16 , riboflavin $6 \cdot 6$, pyridoxine $2 \cdot 2$, menadione sodium bisulphite $1 \cdot 7$, pteroylmonoglutamic acid $1 \cdot 4$, thiamin mononitrate $1 \cdot 1$, biotin $0 \cdot 2$, cyanocobalamin $11 \mu \mathrm{g}$, ethoxyquin 83 .

\|| Twelve diets were formulated by appropriate mixing of $985 \mathrm{~g}$ diet $\mathrm{E}$ with $15 \mathrm{~g}$ of a premix containing 0,1 , 2 or $3 \mathrm{~g} \mathrm{KH}_{2} \mathrm{PO}_{4} / \mathrm{kg}$ (reagent grade; Sigma Chemical Co., St Louis, MO, USA) in a $4 \times 3$ factorial arrangement with three levels of phytase (EC 3.1.3.8; 0,500 or 1000 phytase units $/ \mathrm{kg}$ ).

If By calculation (Feed Formulation, The Brill Corporation, Norcross, GA, USA).

weeks. Experimental diets were formulated from a basal diet (E) that contained 4.63 (SD 0.02) $\mathrm{g}$ total $\mathrm{P} / \mathrm{kg}$ (by analysis), $1.9 \mathrm{~g}$ available $\mathrm{P} / \mathrm{kg}$ (by calculation), and $12 \mathrm{~g} \mathrm{Ca} / \mathrm{kg}$ (by calculation). Diet $\mathbf{E}$ was supplemented with four levels of supplemental inorganic $\mathbf{P}(0$, 1,2 , or $3 \mathrm{~g} / \mathrm{kg}$ ) from reagent-grade $\mathrm{KH}_{2} \mathrm{PO}_{4}$ (Sigma Chemical Co., St Louis, MO, USA), and three levels of phytase $\left(0,500\right.$ and 1000 phytase units (FTU) $/ \mathrm{kg}$, from Natuphos ${ }^{\circledR} 5000$ (Royal Gist Brocades NV, Agro Business Group, Delft, The Netherlands) in a $4 \times 3$ factorial arrangement. Each treatment was replicated four times with five birds per pen. Diets were formulated to contain similar levels of protein $(280 \mathrm{~g} / \mathrm{kg})$, energy $(11.732 \mathrm{MJ} / \mathrm{kg})$, and $\mathrm{Ca}(12 \mathrm{~g} / \mathrm{kg})$. The crude fat and fibre contents of diets $\mathrm{NRC}$ and $\mathrm{E}$ were $54 \cdot 1,4 \cdot 40 \mathrm{~g} / \mathrm{kg}$ and $62 \cdot 7,4 \cdot 86 \mathrm{~g} / \mathrm{kg}$ respectively. Phytase activity was determined before mixing the phytase preparation with other feed ingredients. One unit of phytase activity (FTU) was defined as the amount of enzyme that frees $1 \mu \mathrm{mol}$ inorganic $P$ from $1.5 \mathrm{~mm}$-sodium phytate/min at $\mathrm{pH} 5.5$ and $37^{\circ}$. The protein and energy contributions from the enzyme addition were considered insignificant. 
Assays

Duplicate samples of feed were digested by the wet-ash procedure, which was validated by including standard reference material 1572 (citrus leaves) from the National Institute of Standards and Technology. $P$ concentration was determined colorimetrically by the molybdo-vanadate method (Association of Official Analytical Chemists, 1970). Toe samples were dried at $100^{\circ}$ for $24 \mathrm{~h}$ and ashed in an electric muffle furnace at $600^{\circ}$ for $24 \mathrm{~h}$.

\section{Measurement of intestinal $p H$}

Intestinal $\mathrm{pH}$ was measured in the crop, gizzard and duodenum of four 3-week-old turkeys fed on a starter (NRC) diet. After killing, the intestine was removed and the $\mathrm{pH}$ of intestinal contents was read directly, using a pencil-thin, gel-filled combination electrode (Fisher Scientific, St Louis, MO, USA). The pH values found were 5.28 (SD 0.29), $2 \cdot 71$ (SD 0.54) and 5.98 (SD 0.06) for the crop, gizzard and duodenum respectively. Thus for the in vitro procedure feed samples were adjusted to $\mathrm{pH}$ values of $5 \cdot 25,2.50$ and 6.00 for the three incubation periods simulating the three sections of the intestinal tract.

\section{In vitro digestions and measurements}

Samples of diets were collected during feed preparation and refrigerated. Plastic syringes $(5 \mathrm{ml})$ were prepared by cutting off their Luer-locks to form a plastic tube equipped with piston. A $1 \mathrm{~g}( \pm 0.001 \mathrm{~g})$ sample of maize-soyabean-meal feed, ground through a $1 \mathrm{~mm}$ screen, was weighed into each syringe. The feed sample was hydrated with double-distilled water and $\mathrm{HCl}$ solution so that the concentration of $0.03 \mathrm{M}-\mathrm{HCl}$ in a final volume of $1.5 \mathrm{ml}$ was obtained. When enzyme solution was applied the double-distilled water was partly replaced by the enzyme solution. The contents of each tube were vortexed, the tubes were sealed with Parafilm and incubated in a water bath at $40^{\circ}$ for $30 \mathrm{~min}$. Then $0.5 \mathrm{ml} 1.5 \mathrm{M}-\mathrm{HCl}$ was added to each tube along with $3000 \mathrm{U}$ pepsin, mixed well, vortexed, sealed with Parafilm and reincubated for $45 \mathrm{~min}$ at the same temperature. During pepsin digestion samples were vortexed twice. At the end of this period, $0.65 \mathrm{ml} 1 \mathrm{M}-\mathrm{NaHCO}_{3}$ containing $3.7 \mathrm{mg}$ pancreatin $/ \mathrm{ml}(8 \times$ United States Pharmacopeia (USP)) was added dropwise, with constant stirring, to each tube. The slurries were transferred quantitatively to segments of dialysis tubing (molecular weight cut-off 12000-14000, diameter $16.0 \mathrm{~mm}$; Sigma Chemical Co.) by means of the piston. Segments were placed in $250 \mathrm{ml}$ Erlenmeyer flasks containing $100 \mathrm{ml} 0.1 \mathrm{M}-\mathrm{NaCl}$ in a $0.05 \mathrm{M}$-succinate buffer $(\mathrm{pH} 6 \cdot 0)$ and incubated in a shaking waterbath at $41 \cdot 1^{\circ}$ (the temperature of the dialysate was $40^{\circ}$ ). A ratio of about $25: 1(\mathrm{v} / \mathrm{v})$ between the dialysing medium and segment contents was maintained. Samples of the dialysate were withdrawn at specified time intervals and inorganic phosphate released was determined (Lowry \& Lopez, 1946). Samples of diets were analysed in triplicate by the in vitro procedure.

Evaluation of the in vitro procedure: effect of phosphorus and phytase concentrations Samples of basal diet $E$ were mixed with graded levels of $\mathrm{KH}_{2} \mathrm{PO}_{4}$ to give $0 \cdot 5-4.0 \mathrm{~g} \mathrm{P} / \mathrm{kg}$ diet in $0.5 \mathrm{~g} / \mathrm{kg}$ increments, or with Natuphos ${ }^{\circledR} 5000$ to have phytase activities of $0,250,500$, 1000 and $2000 \mathrm{FTU} / \mathrm{kg}$, and investigated by the in vitro method for the amount of inorganic phosphate released.

\section{Determination of the effect of acid phosphatase activity in commercial phytases on the} rate of dephosphorylation

Phytase (1000 FTU/kg) from different preparations (Natuphos ${ }^{\circledR} 5000$ and crude Aspergillus ficuum phytase; Sigma Chemical Co.) was applied to the basal diet E and the 
kinetics of $P$ release was studied in the course of $240 \mathrm{~min}$ dialysis. In spite of standardizing phytase activity we observed significant differences $(t$ test, $P<0.05)$ in the amounts of $\mathrm{P}$ freed from different samples of the same feed. After $1 \mathrm{~h}$ dialysis the difference amounted to $20.90 \mathrm{mmol} P$, whereas after $3 \mathrm{~h}$ it was $25.45 \mathrm{mmol}$ in favour of the Sigma preparation (results not shown). These preparations also differed in amount of acid phosphatase (AcP) activity (measured against p-nitrophenylphosphate): $14.6 \mathrm{AcP} \mathrm{U} /$ phytase $\mathrm{U} v$. 321 AcP U/phytase U. Thus the possible role of acid phosphatase activity in phytate dephosphorylation was studied using the in vitro assay. Different amounts of phytase (from Natuphos ${ }^{1000}$ ) and acid phosphatase were added in solution to a $1 \mathrm{~g}$ sample of the basal diet, to produce different $\mathrm{AcP} U /$ phytase $\mathrm{U}$ ratios. The ratio found in Natuphos ${ }^{\circledR}$ (14.6 AcP U/phytase $U$ ) was regarded as a unit of enrichment (R).

\section{Application of the in vitro procedure to determine the effect of some tissue degrading activities on the rate of phytate dephosphorylation}

We hypothesized that phytate dephosphorylation in feeds based on maize-soyabean meal would depend not only on phytase activity, but also on the access of phytase to phytate. A partial breakdown of cell walls and the liberation of phytate from complexes with other plant tissue components could therefore accelerate the dephosphorylation process. This hypothesis was tested by introducing exogenous fungal acid protease (EC 3.4.23.6), fungal cellulase (EC 3.2.1.4) and phytase into feed samples. The standard in vitro assay was enhanced by an assay of reducing sugars (dinitrosalicylic acid procedure; Miller, 1959) and by protein determination in the dialysate (Sigma Diagnostics, Protein assay kit, Procedure No. P-56560).

\section{The effect of intracellular phytate-degrading enzymes on phytate hydrolysis in feeds as} determined by the in vitro procedure

Normally, exogenous enzyme is added to feeds in the form of a preparation in which the active protein is freed from any cellular structures. Some feed ingredients, however, contain active phytase (endogenous activity) bound to cellular structures, which may dephosphorylate phytate in the course of the digestion process. Wheat is an example of such an ingredient. On the other hand, an Aspergillus niger mycelium after citric acid fermentation was found to contain high levels of phytate-degrading enzymes, which are either intracellular or bound to cell walls (Żyła et al. 1989). In order to determine whether the in vitro method was able to measure intracellular activity we supplemented the basal diet with 10 and $50 \mathrm{~g} / \mathrm{kg}$ of the dried mycelium, and $10 \mathrm{~g} / \mathrm{kg}$ dried and autoclaved mycelium served as a blank.

\section{The influence of calcium concentration in feeds on the yield of phytate hydrolysis} The Ca:supplemental $\mathbf{P}$ ratio is a well-known factor contributing to the availability of phytate $\mathbf{P}$, as confirmed in several studies with poultry and pigs. We examined the sensitivity of the in vitro procedure to different $\mathrm{Ca}$ levels by decreasing the $\mathrm{Ca}$ content in the diet from 12 to $6 \mathrm{~g} / \mathrm{kg}$, with different levels of phytase activity: 0,500 and $1000 \mathrm{FTU} / \mathrm{kg}$. Phytase was applied in solution to a $1 \mathrm{~g}$ sample of maize-soyabean meal containing 12 or $6 \mathrm{~g} \mathrm{Ca} / \mathrm{kg}$, subjected to the in vitro procedure and analysed for the amount of inorganic $P$ released.

\section{Enzymes and enzyme activity measurements}

The microbial phytase (EC 3.1.3.8) used in the present study (Natuphos ${ }^{\circledR} 5000$, a commercial preparation with a phytase activity of $6250 \mathrm{FTU} / \mathrm{g}$ (declared by the producer)) was provided by Royal Gist Brocades, Agro Business Group, Delft, The Netherlands. 
A crude phytase preparation from Aspergillus ficuum, (P-9792; Sigma Chemical Co.) was also tested in vitro. Phytase activity was determined at $40^{\circ}$ using $2 \mathrm{mmol}$ sodium phytate in $100 \mathrm{~mm}$-acetate buffer ( $\mathrm{pH} \mathrm{4.5)}$ as a substrate. The incubation mixture contained $3 \mathrm{ml}$ substrate and $0.5 \mathrm{ml}$ enzyme solution; the incubation time was $60 \mathrm{~min}$. The reaction was terminated by adding $0.5 \mathrm{ml}$ reaction mixture to $4 \mathrm{ml}$ acetate-acid-molybdate reagent, and the liberated $P$ was determined spectrophotometrically (Heinonen \& Lahti, 1981). One unit of phytase activity (PhytU) was defined as that required to liberate $1 \mu \mathrm{mol}$ inorganic $\mathrm{P}$ in 1 min under the above conditions. Natuphos 5000 had an activity of $250 \mathrm{PhytU} / \mathrm{g}$, while the preparation purchased from Sigma Chemical Co. had an activity of $51 \mathrm{PhytU} / \mathrm{g}$.

Pepsin (P-6887) and pancreatin (P-7545, activity: $8 \times$ USP) were purchased from Sigma Chemical $\mathrm{Co}$. Aspergillus niger mycelium, which contained intracellular as well as cell-wallbound phytase and acid phosphatase, was obtained from the Department of Food Biotechnology, University of Agriculture, Krakow, Poland. Fungal acid protease, type XIII, from Aspergillus saitoi (P-2143; Sigma Chemical Co.) had an activity of $0.8 \mathrm{U} / \mathrm{mg}$ ( $1 \mathrm{U}$ is defined as the amount that hydrolyses haemoglobin to produce colour equivalent to $1.0 \mu \mathrm{mol}$ tyrosine/min at $\mathrm{pH} 2.8$ and $37^{\circ}$ ). Fungal cellulase from Aspergillus niger (C1184; Sigma Chemical Co.) had an activity of $0.49 \mathrm{U} / \mathrm{mg}$ (1 U liberates $1.0 \mu \mathrm{mol}$ glucose from cellulose in $1 \mathrm{~h}$ at $\mathrm{pH} 5.0$ and $37^{\circ}$ ). Acid phosphatase (P-3752; Sigma Chemical Co.) was found to be free of phytase activity. The activity of acid phosphatase was assayed at $40^{\circ}$ using $5.5 \mathrm{~mm}$-disodium p-nitrophenylphosphate in $100 \mathrm{~mm}$-acetate buffer $(\mathrm{pH} 4.5)$. The final volume of the solution containing the enzyme and the substrate was $1.05 \mathrm{ml}$. After $30 \mathrm{~min}$ incubation the reaction was terminated by the addition of $5 \mathrm{ml} 40 \mathrm{~mm}-\mathrm{NaOH}$, and the amount of $p$-nitrophenol released was determined spectrophotometrically at $405 \mathrm{~nm}$. One unit of acid phosphatase activity (AcPU) was equal to $1 \mu \mathrm{mol} p$-nitrophenol liberated $/ \mathrm{min}$.

\section{Statistical analyses}

Data were analysed by the general linear models procedure of Statistical Analysis Systems (1985). In the experiment with turkeys the variances for body-weight gain, feed intake, toe ash and feed efficiency were found to be heterogeneous (Bartlett's test). An attempt to homogenize the variances by following Taylor's power procedure (Fry, 1993) did not produce any increase in the sensitivity of differences detection. ANOVA and regression analysis were performed therefore on non-transformed data and individual standard errors of means were determined for each treatment (Baker, 1986). Means were compared using the least significant difference test $(P<0.05)$. For fitting the in vivo responses to in vitro dialysable P, different models (linear, logarithmic, and 'Hane's transformation') were compared by calculating coefficients of determination as well as the $F$ values for the lack of fit (Fry, 1993). Hane's transformation: $s / v=\left(K_{\mathrm{m}} / V_{\max }\right)+\left(1+V_{\max }\right) s$ is a linearization of the Michaelis-Menten equation: $v=V_{\max } s /\left(K_{\mathrm{m}}+s\right)$ which allows for the determination of kinetic parameters $\left(K_{\mathrm{m}}, V_{\max }\right)$ of an enzymically catalysed reaction (Dixon \& Webb, 1964; Fry, 1993). If the reaction velocities ( $v$ ) for different substrate concentrations $(s)$ are known, then the regression of $s / v v . s$ is performed, and $V_{\max }$ and $K_{\mathrm{m}}$ are calculated from the slope and intercept of the regression line. In the present study, in vivo responses were divided by in vitro $\mathbf{P}$ and then regressed against in vitro $\mathbf{P}$. This procedure is referred to as the 'Hane's transformation'.

\section{RESULTS}

Evaluation of the in vitro procedure: effect of phosphorus and phytase concentrations A linear release of $P$ was observed over the $P$ concentration range investigated (Fig. 1(a)). The phosphate recovery ranged from 93 to $113 \%$ (mean 104, SD 4.39). P release in response to the increasing levels of phytase was linear up to $1000 \mathrm{FTU} / \mathrm{kg}\left(R^{2} 0.987, P<0.0001\right)$. 

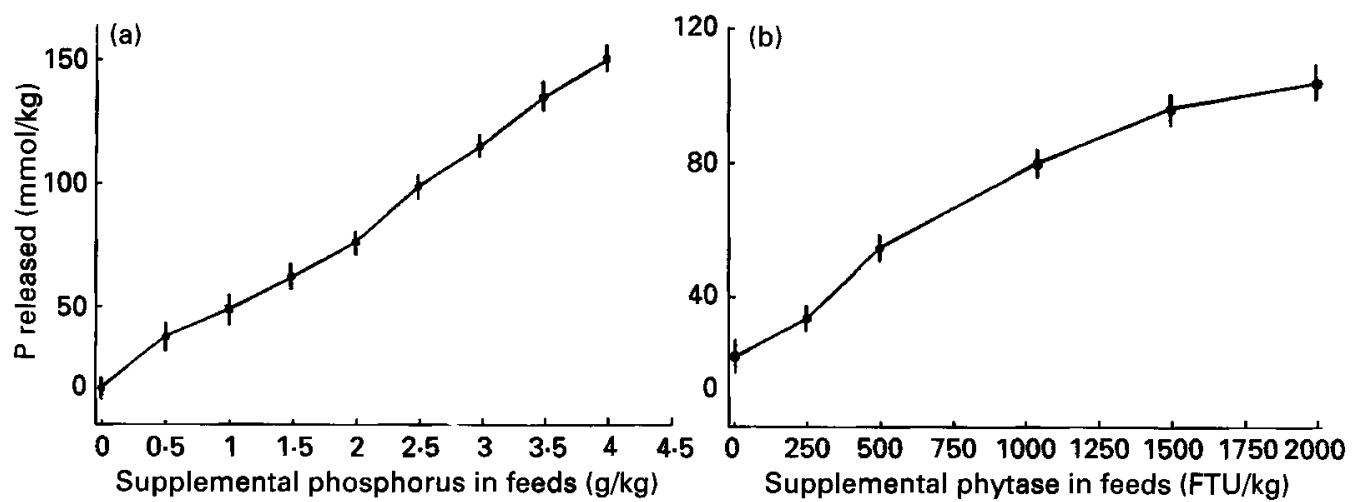

Fig. 1. Effects of (a) phosphorus and (b) phytase (EC 3.1.3.8) concentrations in feeds on the release of phosphorus determined by an in vitro procedure. Phosphorus release in response to increasing levels of phosphorus was linear $\left(R^{2} 0.99, P<0.00001\right)$. For phytase the response was linear up to $1000 \mathrm{FTU} / \mathrm{kg}\left(R^{2} 0.987\right.$, $P<0.0001)$. A quadratic equation better characterized the response over the entire activity range $\left(R^{2} 0.985\right.$, $P<0.0001$ ). For details of feeds and procedures, see Table 1 and pp. $4-6$.

Higher activities $(1500,2000 \mathrm{FTU} / \mathrm{kg})$ produced responses which were better described by a quadratic equation (for $2000 \mathrm{FTU} / \mathrm{kg}: R^{2} 0.985, P<0.0001$ ). The response across all concentrations can be described by the kinetics of an enzymically catalysed reaction, i.e. the quantity of product formation as a function of an enzyme concentration (Fig. 1(b)).

\section{Turkey growth response trial}

A significant phytase $\times P$ interaction was observed for each of the variables studied except feed efficiency (Table 2). In treatments without added phosphate, feed intake, body-weight gain and toe ash responded with significant increases to graded levels of phytase. The increases in feed intake and body gain of turkeys given $1 \mathrm{~g}$ supplemental $\mathrm{P} / \mathrm{kg}$ were attenuated by the addition of 1000 FTU phytase to the diets. Such a decrease, however, was not observed in the percentage of ash in the toes. A further increase in P supplementation $(2 \mathrm{~g} / \mathrm{kg})$ suppressed the increase in feed intake caused by phytase addition. No significant changes in feed intake, gain or toe ash that could be attributed to phytase were observed with $3 \mathrm{~g}$ supplemental $\mathrm{P} / \mathrm{kg}$.

Similarly, the effect of $\mathrm{P}$ on growth and bone mineralization of turkey poults was more pronounced at low levels of phytase supplementation. Feeds which did not contain supplemental phytase promoted better feed intake, body gain and toe ash due to increasing concentration of inorganic P. At $500 \mathrm{FTU} / \mathrm{kg}$ phytase addition, toe ash was improved by 1 or $2 \mathrm{~g}$ added $\mathrm{P} / \mathrm{kg}$, but no further increase was observed with $3 \mathrm{~g}$ added $\mathrm{P} / \mathrm{kg}$. With 1000 FTU supplemental phytase $/ \mathrm{kg}$ in the diets there was a significantly higher percentage of ash in the toes resulting from addition of $1 \mathrm{~g} \mathrm{P} / \mathrm{kg}$. No further increase, however, was caused by higher levels of $P$ supplementation. Feed efficiency was not affected by increasing levels of phytase in poults fed on diets supplemented with 0,1 or $3 \mathrm{~g} \mathrm{P} / \mathrm{kg}$. However, in birds receiving $2 \mathrm{~g}$ inorganic $\mathrm{P} / \mathrm{kg}$ diet, feed efficiency was improved by the addition of 500 or $1000 \mathrm{FTU}$ phytase. In general, toe ash, feed intake, and body-weight gain showed asymptotic responses to both phytase and $\mathrm{P}$. The rate of fall-off from the asymptotes can be related to the degree to which $P$ or phytase was lacking in the diets.

\section{In vitro dialysable phosphorus}

A significant phytase $\times$ phosphate interaction $(P<0.0001)$ existed for in vitro dialysable inorganic $\mathrm{P}$. There was a linear increase in release of $\mathrm{P}$ from feeds containing graded levels 
Table 2. Effect of dietary phosphorus and phytase (EC 3.1.3.8) activity on performance and bone mineralization of turkey poults, and in vitro dialysable phosphorus*

(Mean values with their standard errors for five pen values)

\begin{tabular}{|c|c|c|c|c|c|c|c|c|}
\hline \multirow{3}{*}{$\begin{array}{l}\text { Phytase } \\
\text { (FTU/kg) }\end{array}$} & \multicolumn{8}{|c|}{ Added phosphorus (g/kg diet) } \\
\hline & \multicolumn{2}{|l|}{0} & \multicolumn{2}{|l|}{1} & \multicolumn{2}{|l|}{2} & \multicolumn{2}{|l|}{3} \\
\hline & Mean & SE & Mean & SE & Mean & $\mathrm{SE}$ & Mean & $\mathrm{SE}$ \\
\hline \multicolumn{9}{|c|}{ Feed intake $\dagger(g)$} \\
\hline 0 & $264^{\mathrm{Aa}}$ & 7 & $393^{\mathrm{Ba}}$ & 9 & $442^{\mathrm{Ca}}$ & 6 & $441^{C a}$ & 14 \\
\hline 500 & $373^{A b}$ & 12 & $430^{\mathrm{Bb}}$ & 9 & $445^{\mathrm{BCa}}$ & 4 & $454^{\mathrm{Cu}}$ & 1 \\
\hline 1000 & $408^{\mathrm{Ac}}$ & 13 & $440^{\mathrm{Bb}}$ & 4 & $441^{\mathrm{Ba}}$ & 11 & $445^{\mathrm{Ba}}$ & 7 \\
\hline \multicolumn{9}{|l|}{ Gain ${ }^{\prime}(\mathrm{g})$} \\
\hline 0 & $164^{\mathrm{Aa}}$ & 8 & $289^{\mathrm{Ba}}$ & 9 & $328^{\mathrm{Ca}}$ & 6 & $346^{\mathrm{Ca}}$ & 9 \\
\hline 500 & $254^{\mathrm{Ab}}$ & 9 & $325^{\mathrm{Bb}}$ & 11 & $348^{\mathrm{Bcb}}$ & 5 & $359^{\mathrm{Ca}}$ & 11 \\
\hline 1000 & $279^{A c}$ & 7 & $336^{\mathrm{Bb}}$ & 4 & $361^{\mathrm{Cb}}$ & 7 & $372^{\mathrm{Ca}}$ & 6 \\
\hline \multicolumn{9}{|c|}{ Feed efficiency (gain/feed) $\ddagger$} \\
\hline 0 & $0.62^{\mathrm{As}}$ & 0.03 & $0 \cdot 73^{\mathrm{Ba}}$ & 0.02 & $0 \cdot 74^{\mathrm{Ba}}$ & 0.02 & $0 \cdot 78^{\mathrm{Ba}}$ & 0.01 \\
\hline 500 & $0.68^{\mathrm{AE}}$ & 0.02 & $0.76^{\mathrm{Bg}}$ & $0 \cdot 02$ & $0.78^{\mathrm{Bab}}$ & 0.02 & $0.79^{\mathrm{Ba}}$ & 0.02 \\
\hline 1000 & $0 \cdot 68^{\mathrm{Aa}}$ & 0.01 & $0 \cdot 77^{8 \mathrm{Ba}}$ & $0-02$ & $0 \cdot 82^{\mathrm{Cb}}$ & 0.02 & $0.82^{\mathrm{Ca}}$ & 0.01 \\
\hline \multicolumn{9}{|c|}{ Toe $\operatorname{ash} \dagger(\mathrm{mg} / \mathrm{g})$} \\
\hline 0 & $64 \cdot 1^{\mathrm{Aa}}$ & $1 \cdot 1$ & $94 \cdot 1^{\mathrm{Ba}}$ & $2 \cdot 0$ & $138 \cdot 4^{\mathrm{Ca}}$ & $1 \cdot 5$ & $149 \cdot 8^{\mathrm{Da}}$ & $3 \cdot 3$ \\
\hline 500 & $85.4^{\mathrm{Ab}}$ & $2 \cdot 6$ & $126 \cdot 2^{\mathrm{Bb}}$ & $1 \cdot 1$ & $149 \cdot 1^{\mathrm{Cb}}$ & 1.8 & $144 \cdot 5^{\mathrm{Ca}}$ & $2 \cdot 3$ \\
\hline 1000 & $96 \cdot 6^{\mathrm{AC}}$ & $3 \cdot 8$ & $139 \cdot 1^{\mathrm{Be}}$ & $4 \cdot 3$ & $146 \cdot 1^{\mathrm{Bb}}$ & $2 \cdot 2$ & $146 \cdot 5^{\mathrm{Ba}}$ & 1.9 \\
\hline \multicolumn{9}{|c|}{ In vitro $\mathrm{P} \S \|(\mathrm{mmol} / \mathrm{kg})$} \\
\hline 0 & $13 \cdot 55^{\mathrm{Aa}}$ & & $53 \cdot 23^{\mathrm{Ba}}$ & & $70 \cdot 65^{\mathrm{Ca}}$ & & $103 \cdot 87^{\mathrm{Da}}$ & \\
\hline 500 & $42 \cdot 26^{\mathrm{Ab}}$ & & $68 \cdot 39^{\mathrm{Bb}}$ & & $110 \cdot 97^{\mathrm{Cb}}$ & & $140 \cdot 32^{\mathrm{Db}}$ & \\
\hline 1000 & $65 \cdot 16^{\mathrm{Ac}}$ & & $81.94^{\mathrm{Bc}}$ & & $118 \cdot 71^{\mathrm{Cb}}$ & & $162 \cdot 58^{\mathrm{Dc}}$ & \\
\hline Pooled SEM & 6.96 & & & & & & & \\
\hline
\end{tabular}

$\mathbf{a}, \mathbf{b}, \mathbf{c}$ Values of the same variable within a column bearing different superscript letters were significantly different, $P<0.05$ (least significant difference).

$A, B, C, D$ Values of the same variable within a row bearing different superscript letters were significantly different, $P<0.05$ (least significant difference).

* For details of diets and procedures, see Table 1 and pp. 4-6.

† Probabilities associated with main effects (ANOVA) were: phosphorus (df 3,48) 0.0001; phytase (df 2, 48) 0.0001 ; phosphorus $\times$ phytase (df 6, 48) 0.0001 .

\$ Probabilities associated with main effects (ANOVA) were: phosphorus (df 3,48) 0.0001; phytase (df 2,48 ) 0.0001 ; phosphorus $\times$ phytase (df 6, 48) 0.5932 .

$\S$ Probabilities associated with main effects (ANOVA) were: phosphorus (df 3,24) 0.0001; phytase (df 2, 24) 0.0001 ; phosphorus $\times$ phytase (df 6, 24) 0.5932 .

$\|$ Analysis performed in triplicate.

of phosphate. Phytase addition also resulted in significant increases in $\mathrm{P}$ release from diets by the in vitro assay. At 0,1 , and $3 \mathrm{~g}$ added $\mathrm{P} / \mathrm{kg}$ these increases were significant, while at $2 \mathrm{~g} / \mathrm{kg}$ the increase caused by $1000 \mathrm{FTU}$ phytase was not significantly higher than with $500 \mathrm{FTU} / \mathrm{kg}$.

Different regression models (linear, logarithmic, and 'Hane's transformation') were tested to determine the ability of the in vitro method to predict in vivo responses (Table 3). The linear model accounted for $71 \%$ of the variation in body-weight gain observed in the in vivo study. The logarithmic model explained $88 \%$ of the response in gain, while 'Hane's transformation' predicted $97 \%$ of the variability in body-weight gain without significant lack of fit. Linear regression for other variables accounted for $68 \%$ of response in toe ash, $57 \%$ of that for feed intake and $59 \%$ for feed efficiency. Generally, 'Hane's transformation' produced a very good model for body-weight gain and feed intake (covering $99 \%$ of the 
Table 3. Different regression models tested for fitting the in vitro results and the results from an in vivo experiment with turkeys

\begin{tabular}{|c|c|c|c|c|c|c|c|}
\hline \multirow[b]{2}{*}{ Parameter } & \multirow[b]{2}{*}{ Model } & \multirow[b]{2}{*}{$R^{2}$} & \multirow{2}{*}{$\begin{array}{l}\text { Fit } \\
F^{4}\end{array}$} & \multicolumn{2}{|c|}{ Intercept } & \multicolumn{2}{|c|}{ Slope } \\
\hline & & & & Estimate & SE & Estimate & SE \\
\hline \multirow[t]{3}{*}{ Body-wt gain (g) } & LIN & 0.712 & 14.40 & 208.86 & 20.09 & $39 \cdot 20$ & $6 \cdot 81$ \\
\hline & LOG & 0.884 & $2 \cdot 92$ & $241 \cdot 85$ & $6 \cdot 34$ & $200 \cdot 14$ & $14 \cdot 03$ \\
\hline & HAN* & 0.973 & 1.91 & 0.001852 & 0.0002 & 0.002330 & 0.00005 \\
\hline \multirow[t]{3}{*}{ Toe ash $(\mathrm{mg} / \mathrm{g})$} & LIN & 0.677 & $40 \cdot 0$ & $72 \cdot 344$ & $11 \cdot 3$ & $19 \cdot 12$ & $\mathbf{3 . 8}$ \\
\hline & LOG & 0.778 & 26.0 & 89.963 & 6.4 & 93.37 & $14 \cdot 2$ \\
\hline & HAN & 0.906 & $23 \cdot 2$ & 0.62167 & 0.07 & 0.54057 & 0.02 \\
\hline \multirow[t]{3}{*}{ Feed intake (g) } & LIN & 0.566 & 14.63 & $329 \cdot 27$ & 23.00 & 31.97 & 7.80 \\
\hline & LOG & 0.829 & $3 \cdot 31$ & $351 \cdot 40$ & $7 \cdot 91$ & 176.6 & $17 \cdot 5$ \\
\hline & HAN & 0.988 & $1 \cdot 00$ & 0.00072 & 0.00009 & 0.002046 & 0.00003 \\
\hline \multirow{3}{*}{$\begin{array}{l}\text { Feed efficiency } \\
\text { (gain:feed) }\end{array}$} & LIN & 0.587 & 2.47 & 0.6408 & 0.019 & 0.0404 & 0.006 \\
\hline & LOG & 0.626 & 1.64 & 0.6795 & 0.011 & 0.1933 & 0.024 \\
\hline & HAN & 0.984 & $2 \cdot 13$ & 0.3522 & 0.057 & $1 \cdot 1685$ & 0.019 \\
\hline
\end{tabular}

LIN, linear; LOG, logarithmic; HAN, Hane's transformation.

* In vivo responses were divided by in vitro $\mathbf{P}$ and then regressed against in vitro $\mathbf{P}$ (analogous to Hane's plot used in enzyme kinetics to determine the Michaelis-Menten constant).

$\dagger$ (Lack of fit mean square/pure error mean square). $F_{0-05}(10,48)=2 \cdot 03 ; F_{0-01}(10,48)=2 \cdot 71$.

observed variability), with a good fit. It resulted, however, in a significant lack of fit when applied to feed efficiency and toe ash.

\section{The effect of acid phosphatase activity in commercial phytases on the rate of dephosphorylation}

Acid phosphatase activity, when applied to feed at two different concentrations ( $R$ 20, $R$ 40), did not significantly change the amount of $P$ released (Fig. 2). Apparently acid phosphatase was not able to hydrolyse phytate in the absence of phytase. In a mixture with 1000 FTU phytase $/ \mathrm{kg}$, acid phosphatase addition ( $R$ 20) resulted in a significant increase in the amount of dialysable $P$ released from maize-soyabean feed. Further enrichment however ( $R$ 40, $R$ 80) did not result in any further increase in dephosphorylation.

\section{Effects of tissue-degrading activities on the rate of phytate dephosphorylation}

Results of the experiment are presented in Table 4. A phytase activity of 500 FTU $/ \mathrm{kg}$ not only significantly increased the amount of $P$ released from maize-soyabean meal, but also had a pronounced effect on the amount of dialysable protein and the concentration of reducing sugars in the dialysate. A further increase in phytase activity $(1000 \mathrm{FTU} / \mathrm{kg})$, however, did not significantly influence the extent of proteolysis or saccharification. The addition of fungal acid protease $(5000 \mathrm{U} / \mathrm{kg}$ ) along with $500 \mathrm{FTU}$ phytase $/ \mathrm{kg}$ had a positive effect on the extent of feed proteolysis, slightly increased the concentration of reducing sugars and increased dephosphorylation by $15 \%$. The extent of maize-soyabeanmeal feed dephosphorylation was further enhanced by the addition of fungal cellulase $(5000 \mathrm{U} / \mathrm{kg})$ to a mixture of the two previously studied enzymes. The amount of reducing sugars in the dialysate increased significantly as a result of cellulolytic saccharification. It could be concluded that phytase activity of $1000 \mathrm{FTU} / \mathrm{kg}$ can be reduced by half without negatively influencing the dephosphorylation rate, when appropriate tissue-degrading activities are present during the reaction 


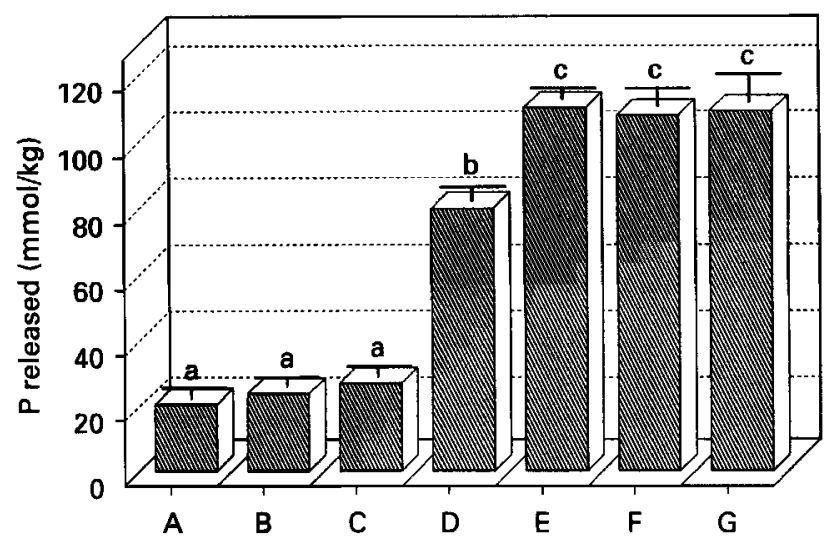

Fig. 2. The influence of acid phosphatase (EC 3.1.3.2) on the dephosphorylation of maize-soyabean-meal feed by phytase (EC 3.1.3.8). The acid phosphatase: phytase ratio (14.6:1) characteristic of Natuphos 5000 was regarded as 1 unit of enrichment (R). Treatments were: A, control (no enzyme); B, acid phosphatase (R 20); C, acid phosphatase (R 40); D, phytase (1000 FTU/kg); E, phytase (1000 FTU/kg) + acid phosphatase (R 20); F, phytase (1000 FTU/kg) + acid phosphatase (R 40); G, phytase (1000 FTU/kg) + acid phosphatase (R 80). Values are means with their standard errors indicated by vertical bars. ${ }^{a, b, c}$ Mean values with unlike superscript letters were significantly different, $P<0.05$ (Student's $t$ test). For details of feeds and procedures, see Table 1 and pp. 4-7.

Table 4. Effect of fungal acid protease (EC 3.4.23.6) and Aspergillus niger cellulase (EC 3.2.1.4) on the rate of phytate dephosphorylation in maize-soyabean-meal feed by a phytase (EC 3.1.3.8) preparation (Natuphos ${ }^{(5000) *}$

(Mean values with their standard errors for samples run in triplicate)

\begin{tabular}{|c|c|c|c|c|c|c|}
\hline \multirow[b]{2}{*}{ Treatment } & \multicolumn{2}{|c|}{$\begin{array}{l}\text { P released } \\
(\mathrm{mmol} / \mathrm{kg})\end{array}$} & \multicolumn{2}{|c|}{$\begin{array}{l}\text { Reducing sugars } \\
\text { (mmol glucose } / \mathrm{kg} \text { ) }\end{array}$} & \multicolumn{2}{|c|}{$\begin{array}{l}\text { Lowry protein } \\
(\mathrm{g} / \mathrm{kg})\end{array}$} \\
\hline & Mean & SE & Mean & $\mathrm{SE}$ & Mean & SE \\
\hline Basal diet (no enzyme) & $23 \cdot 3^{\mathrm{a}}$ & 1.49 & $96 \cdot 9^{\mathrm{a}}$ & $4 \cdot 5$ & $41 \cdot 5^{8}$ & 0.73 \\
\hline Phytase (500 FTU/kg) & $78 \cdot 6^{b}$ & $2 \cdot 25$ & $114 \cdot 3^{a b}$ & $5 \cdot 9$ & $48 \cdot 6^{b}$ & 1.87 \\
\hline Phytase $(1000$ FTU/kg) & $92 \cdot 0^{\mathrm{c}}$ & 2.03 & $121 \cdot 0^{\mathrm{ab}}$ & $11 \cdot 0$ & $49 \cdot 3^{b}$ & $1 \cdot 43$ \\
\hline $\begin{array}{l}\text { Phytase }(500 \mathrm{FTU} / \mathrm{kg})+\text { fungal acid } \\
\text { protease }(5 \mathrm{U} / \mathrm{g})\end{array}$ & $90 \cdot 2^{\mathrm{e}}$ & $2 \cdot 86$ & $126 \cdot 8^{b}$ & $9 \cdot 6$ & $55 \cdot 6^{\mathrm{c}}$ & $1 \cdot 08$ \\
\hline $\begin{array}{l}\text { Phytase }(500 \mathrm{FTU} / \mathrm{kg})+\text { fungal acid } \\
\text { protease }(5 \mathrm{U} / \mathrm{g})+A \text {. niger cellulase } \\
(5 \mathrm{U} / \mathrm{g})\end{array}$ & $102 \cdot 5^{d}$ & 1.66 & $181 \cdot 3^{\mathrm{e}}$ & $8 \cdot 9$ & $59 \cdot 2^{d}$ & $1 \cdot 88$ \\
\hline
\end{tabular}

a,b,c,d Mean values within a column with unlike superscript letters were significantly different, $P<0.05$ (Student's $t$ test).

* For details of feed and procedures, see Table 1 and pp. 4-8.

Intracellular phytate-degrading enzymes hydrolyse phytates in feeds as determined by the in vitro procedure

The $10 \mathrm{~g} / \mathrm{kg}$ feed supplementation with a dried Aspergillus niger mycelium resulted in a response $(91.98 \mathrm{mmol} \mathrm{P} / \mathrm{kg})$ equivalent to $1000 \mathrm{FTU} / \mathrm{kg}$, whereas $50 \mathrm{~g} / \mathrm{kg}$ supplementation caused complete conversion $(152.0 \mathrm{mmol} \mathrm{P} / \mathrm{kg})$ of total into inorganic $\mathrm{P}$. The release of $\mathrm{P}$ 


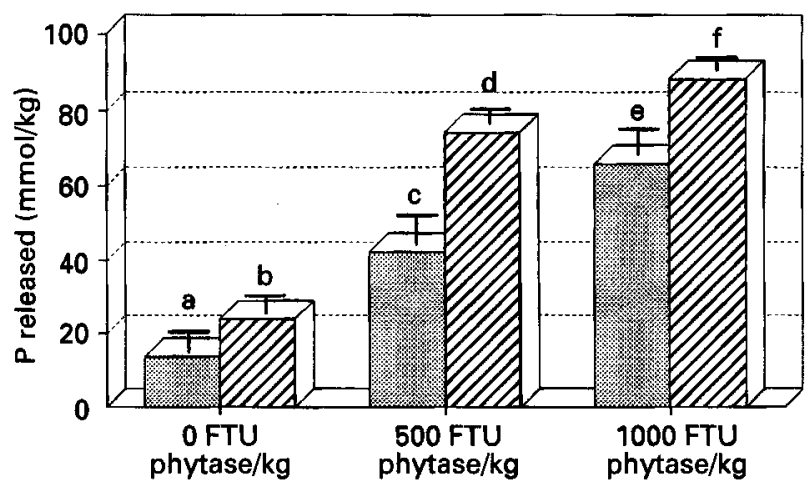

Fig. 3. The influence of calcium concentration on the amount of inorganic phosphorus released from a maize-soyabean-meal feed by phytase $(E C 3 \cdot 1 \cdot 3.8)$. (圈), $12 \mathrm{~g} \mathrm{Ca} / \mathrm{kg}$ diet; $(\square), 6 \mathrm{~g} \mathrm{Ca} / \mathrm{kg}$ diet. Values are means with their standard errors indicated by vertical bars. $a, b, c, d, e,{ }_{i}$ Mean values with unlike superscript letters were significantly different, $P<0.05$ (Student's $t$ test). For details of feed and procedures, see Table 1 and pp. $4-7$.

from the basal diet $(20.5 \mathrm{mmol} / \mathrm{kg})$ was not changed significantly $(20.49 \mathrm{mmol} / \mathrm{kg})$ when supplemented with $10 \mathrm{~g}$ autoclaved mycelium $/ \mathrm{kg}$ (results not shown).

The influence of calcium concentration in feeds on the yield of phytate hydrolysis A decrease in Ca content of the diet from 12 to $6 \mathrm{~g} / \mathrm{kg}$ resulted in a significant increase in the amount of inorganic $P$ released from maize-soyabean-meal diets at each level of added phytase (0, 500, and $1000 \mathrm{FTU} / \mathrm{kg}$, Fig. 3).

\section{DISCUSSION}

The enzymic activity of phytase is measured in vitro using a pure substrate and standardized conditions. Differences exist in phytase assays ( $\mathrm{pH}$ from 2.5 to 5.5 ; substrate concentration from $1.5 \mathrm{~mm}$-sodium phytate to $42 \mathrm{mM}-\mathrm{Mg}-\mathrm{K}$ phytate; temperature 37 or $40^{\circ}$ ) reported in the literature. This affects enzyme activity, e.g. 600 'Sigma units' used by Edwards (1993) in studies with broilers as the highest dosage equals 140-150 FTU. There is a need, therefore, for a standardized assay capable of predicting the efficacy of different feed enzymes under conditions similar to those applied in practice.

The in vitro method described in the present paper simulates digestive conditions in the crop, gizzard and duodenum. The crop $\mathrm{pH}$ of turkeys fed on maize-soyabean meal was $5 \cdot 28$, which is similar to the optimal $\mathrm{pH}$ for phytase; therefore in the crop simulation, $\mathrm{pH}$ was held at $5 \cdot 25$. The feed: water ratio, which may affect solubility of substrate and velocity of reactions, was kept within physiological limits and a constant proportion of feed weight to digestive enzymes was maintained. Simulation of digestive conditions in the small intestine is considered to be the most critical step for in vitro methods used to predict the absorption of minerals (Hunt et al. 1987). Because phytase is inhibited by phosphate, and pancreatic enzymes can undergo end-product inhibition, a discrimination between low- and high-molecular-weight soluble compounds was made under conditions simulating gradient absorption from the duodenum (dialysis). In contrast to previously reported procedures, the initial $\mathrm{pH}$ and the osmolarity of the dialysate were standardized; a ratio of about $1: 25$ $(\mathrm{v} / \mathrm{v})$ was maintained between the digesta and the dialysing medium. Gastrointestinal transit times, which influence the extent of digestion and absorption, depend on many factors which are difficult to reproduce in vitro. Golian \& Maurice (1992) reported a clearance time of 2.5-3 h for 2-3-week-old broiler chicks and 3.5-4h for poults aged 4-6 weeks. It is hard to determine, however, how that time should be divided among different 
parts of the intestine. In our procedure the pepsin digestion time and pepsin concentration reported by Bedford \& Classen (1993) were adopted. The time of pancreatin digestion $(240 \mathrm{~min})$ was chosen on the basis of the best correlation found between the dialysable $\mathrm{P}$ and body-weight gains of turkeys.

The amount of inorganic $\mathbf{P}$ released by the in vitro assay increased linearly with increasing concentrations of inorganic phosphate in feed samples. Similarly, the changes in inorganic $\mathbf{P}$ concentration of the dialysate resulting from different phytase activities in feeds suggest that the assay is accurate enough for monitoring effects of different phytase levels on inorganic phosphate release from feeds.

Turkeys have a high requirement both for $\mathrm{Ca}(12 \mathrm{~g} / \mathrm{kg}$ diet) and available $\mathrm{P}(6 \mathrm{~g} / \mathrm{kg}$ diet; National Research Council, 1984). The Ca:available $\mathrm{P}$ ratio is a major factor contributing to the retention of phytate $P$ (Sanders et al. 1992), and is especially important in diets deficient in $\mathrm{P}$ (Vandepopuliere et al. 1961). Mohammed et al. (1991) reported that with reduced inorganic $P$ and increased cholecalciferol levels in broiler diets, an increase in phytate $P$ utilization of up to $65 \%$ was observed. The $\mathrm{Ca}: \mathrm{P}$ ratio also influences the extent of phytate hydrolysis by phytase (von Schöner et al. 1993). In the present experiment turkeys were given $12 \mathrm{~g} \mathrm{Ca} / \mathrm{kg}$ diet. However, the birds' requirement for $\mathrm{P}$ (National Research Council, 1984) would only be met in the treatment with $3 \mathrm{~g}$ supplemental $\mathrm{P} / \mathrm{kg}$ and 1000 FTU phytase/kg (assuming $1000 \mathrm{FTU} / \mathrm{kg}$ from Natuphos ${ }^{(1)} 5000$ to be equivalent to $1 \mathrm{~g}$ inorganic $\mathrm{P} / \mathrm{kg}$; Vogt, 1992). All the other treatments were $\mathrm{P}$ deficient but met the $\mathrm{Ca}$ requirement. Increasing the level of $\mathrm{P}$ in the diet not only increased the amount of available $\mathbf{P}$, but also improved the $\mathrm{Ca}: \mathrm{P}$ ratio. Phytase can dephosphorylate phytate, increasing available $P$ and improving the $\mathrm{Ca}: \mathrm{P}$ ratio, in spite of a possible increase in $\mathrm{Ca}$ utilization resulting from phytase action. The question arises therefore whether these two phenomena are synergistic. The amounts of dialysable $\mathbf{P}$ determined by the in vitro assay seem to support such a hypothesis.

Body-weight gain was slightly better correlated with in vitro $P$ release $(R 0.847)$ than was toe ash $(R 0.817)$. The in vitro procedure was better in predicting responses at lower levels of phytase and $\mathrm{P}$ supplementation, while at the highest levels the linear model applied to the in vitro measurements overestimated the actual in vivo responses. Fritz et al. (1969) reported that the percentage toe ash and the weight gain of broiler chicks aged 3 weeks were correlated with the logarithm of the P content of the diet. When the responses obtained using the in vitro method were linearized by logarithmic transformation, the correlations with body-weight gain and toe ash were 0.940 and 0.882 respectively $(P<0.0001)$. The best linearization method found, however, was the 'Hane's transformation', which resulted in the best fit with all the in vivo data, except for feed efficiency. This raises the intriguing possibility that the Michaelis-Menten equation, subsequently modified by Monod in 1942 to describe the relationship between microbial growth rate and the concentration of a growth-limiting nutrient (Fry, 1993), can be applied to higher organisms, provided that a good analytical method for determining nutrient availability from feed is available. This will be addressed in more detail elsewhere.

Vandepopuliere et al. (1961) found that increased utilization of phytate P led to improved growth rather than increased bone ash, similar to the results of the present experiment. It can be concluded that for diets rich in phytase and supplemental phosphate with adequate $\mathrm{Ca}$ and cholecalciferol levels $(96.4 \mu \mathrm{g} / \mathrm{kg}$ diet $)$, the $\mathrm{P}$ released by means of enzyme action is utilized for growth rather than for bone mineralization. The growthpromoting character of $\mathbf{P}$ released by the action of phytase can possibly be partly attributed to the increased concentration of myo-inositol, the final product of phytate dephosphorylation, which is believed to stimulate growth of chicks, turkeys, rats, and mice (Combs, 1992).

With broiler chicks receiving graded levels of phytase and supplemental phosphate, 
Denbow et al. (1993) reported increased feed intake and body-weight gain. Similar responses were also observed in young turkeys given supplemental phytase and phosphate (Ravindran et al. 1993). In contrast, we did not observe any significant changes in feed intake responses at 2 and $3 \mathrm{~g} / \mathrm{kg}$ levels of inorganic phosphate supplementation. The amounts of $\mathrm{P}$ released as determined by the in vitro procedure were moderately $(R 0.766)$ correlated with feed intakes. No effect of varying $\mathbf{P}$ and $\mathrm{Ca}$ concentrations on feed efficiency was found by Sanders et al. (1992). The results of the present study seem to confirm this observation but only in treatments supplemented with inorganic phosphate. Phytase addition improved feed efficiency at a supplementation level of $2 \mathrm{~g} \mathrm{P} / \mathrm{kg}$, the increases at the other levels failed to be significant. On the other hand the increases in feed efficiency were correlated (see Table 3 ) with the amounts of $\mathbf{P}$ released by the in vitro procedure.

Acid phosphatase activity can accelerate phytate dephosphorylation by phytase with sodium phytate as the substrate (Żyła, 1993) or with rapeseed phytates ( $\dot{Z} y$ la \& Koreleski, 1993). The present study indicates that this effect occurs for maize-soyabean-meal feed subjected to simulated intestinal conditions. These findings demonstrate the importance of acid phosphatase activity in commercial phytase preparations intended for use in the feed industry.

The in vitro procedure described was applied to measure the extent of feed proteolysis and saccharification. The effect of enzymic phytate degradation on the extent of feed proteolysis observed in the present study confirms that the removal of phytate from soyabean protein improves its digestibility (Ritter et al. 1987). Ketaren et al. (1993) credited phytase with 'proteolytic activity', as it increased live-weight gain, protein retention, and daily protein deposition in pigs. Acid proteinase activity was found in aleurone grains of plant seeds (Yatsu \& Jacks, 1968), along with phytates, and thus can be suspected to play a role in phytate dephosphorylation during seed germination. We found that exogenous fungal acid protease $(5000 \mathrm{U} / \mathrm{kg})$ when applied to a maize-soyabean-meal feed along with 500 FTU phytase/kg increased proteolysis yield and enhanced dephosphorylation. This effect was magnified as a result of coapplication of Aspergillus niger cellulase $(5000 \mathrm{U} / \mathrm{kg})$ to the mixture of phytase and acid protease enzymes. The positive influence of cellulolytic activity on the enzymic hydrolysis of phytic acid in soyabean meal has been reported by Han (1988). In contrast to our findings, however, he did not observe any positive influence of bromelain (EC 3.4.22.4; plant protease) on dephosphorylation. Soyabean meal which was subjected by Han to a single incubation at pH 5.4 created certainly a different substrate from the full feed formulation which was subjected to the conditions employed in our studies. The intracellular phytate-degrading enzymes from the waste Aspergillus niger mycelium left after citric acid fermentation have been characterized previously (Żyla et al. 1989). In the present study they were applied to the maize-soyabean-meal feed as a supplement at two different concentrations, and the in vitro method was found to be useful in quantifying activities of enzymes which are either intracellular or bound to cell walls.

Interaction of dietary $\mathrm{P}$ with $\mathrm{Ca}$ in maize-soyabean meal can be expected to take place not only during or after absorption of these minerals, but also before absorption, in the gastrointestinal tract. Saio et al. (1968) indicated that the 11S protein in soyabean can bind more phytate when $\mathrm{Ca}$ is present. High levels of dietary $\mathrm{Ca}$ are thought to inhibit $\mathrm{P}$ absorption by forming insoluble $\mathrm{Ca}-\mathrm{P}$ complexes in the intestine (Guyton, 1986). High levels of dietary $\mathrm{Ca}$ may form insoluble complexes with phytate that are resistant to enzyme action (Fisher, 1993). The effect of dietary Ca concentration on dialysable $P$ release was demonstrated in the present study. Reducing the Ca concentration from 12 to $6 \mathrm{~g} / \mathrm{kg}$ caused a significant increase in the amount of $P$ freed from the basal maize-soyabean-meal diet, and significantly increased the amount of $P$ released by phytase, both at 500 and at $1000 \mathrm{FTU} / \mathrm{kg}$. 
In conclusion, it can be postulated that the in vitro procedure described here simulated the digestive conditions of the intestinal tract of turkeys. It predicted $\mathbf{P}$ bioavailability in maize-soyabean-meal feeds containing different concentrations of inorganic $\mathbf{P}$ and (or) phytase. It allowed for measurement of the $\mathbf{P}$ release, extent of proteolysis, and carbohydrate digestion resulting from phytase, acid phosphatase, fungal acid protease and cellulase addition to feeds. Enzyme preparations can be added to feeds in solution for the measurement of theoretical $(100 \%)$ values of hydrolysis, or mixed with other ingredients during feed preparation before in vitro analysis. The procedure was shown to be sensitive to $\mathrm{Ca}$ concentration in feeds. Finally, the in vitro method described is accurate, reasonably rapid, cheap, simple and robust. It is expected to be easily modified for different species, types of feeds, and nutrients.

The authors would like to acknowledge the 'Gist Brocades' company (The Netherlands) for supplying the Natuphos ${ }^{*} 5000$ preparation used throughout the study. Author K. Żyla expresses his appreciation to the Miller Fund (administered by the Department of Animal Sciences, University of Missouri) for financial support. This study was supported in part by the Department of the Interior, U.S. Geological Survey, through the Missouri Water Resources Center.

This is a contribution from the Missouri Agricultural Experiment Station. Journal Series Number 12083.

\section{REFERENCES}

Association of Official Analytical Chemists (1970). Animal feeds. Phosphorus. 7.095-7.098. Photometric method. In Official Methods of Analysis, p. 125. Washington DC: Association of Official Analytical Chemists.

Baker, D. H. (1986). Problems and pitfalls in animal experiments designed to establish dietary requirements for essential nutrients. Journal of Nutrition 116, 2339-2349.

Bedford, M. R. \& Classen, H. L. (1993). An in vitro assay for prediction of broiler intestinal viscosity and growth when fed rye-based diets in the presence of exogenous enzymes. Poultry Science 72, 137-143.

Champagne, E. T. \& Phillippy, B. Q. (1989). Effects of pH on calcium, zinc and phytates solubilities and complexes following in vitro digestions of soy protein. Journal of Food Science 54, 587-592.

Combs, G. F. (1992). The Vitamins. Fundamental Aspects in Nutrition and Health, pp. 411-415. San Diego: Academic Press.

Denbow, D. M., Ravindran, V., Kornegay, E. T., Self, B. B. \& Hulet, R. M. (1993). Improved availability of phosphorus in soya bean meal for broiler chicks by supplemental phytase. Poultry Science 72, Suppl. 1, 250 Abstr.

Dixon, M. \& Webb, E. C. (1964). Enzyme kinetics. Michaelis theory. In Enzymes, pp. 63-70. New York: Academic Press.

Edwards, H. M. (1993). Dietary 1,25-dihydroxycholecalciferol supplementation increases natural phytate phosphorus utilization in chickens. Journal of Nutrition 123, 567-577.

Fisher, H. (1993). Low-calcium diets enhance phytate-phosphorus availability. Nutrition Reviews 50, $170-171$.

Fritz, J. C., Roberts, T., Boehne, J. W. \& Hove, E. L. (1969). Factors affecting the chick's requirement for phosphorus. Poultry Science 48, 307-320.

Fry, J. C. (1993). Biological Data Analysis. A Practical Approach, pp. 14-21. Oxford, New York, Tokyo: IRL Press.

Golian, A. \& Maurice, D. V. (1992). Dietary poultry fat and gastrointestinal transit time of feed and fat utilization in broiler chickens. Poultry Science 71, 1357-1363.

Guyton, A. C. (1986). Medical Physiology, 7th ed., p. 937. Philadelphia: W. B. Saunders and Company.

Han, Y. W. (1988). Removal of phytic acid from soybean and cottonseed meals. Journal of Agricultural and Food Chemistry 36, 1181-1183.

Heinonen, J. K. \& Lahti, R. J. (1981). A new and convenient colorimetric determination of inorganic orthophosphate and its application to the assay of inorganic pyrophosphatase. Analytical Biochemistry 113, 313-317.

Hunt, J. R., Johnson, P. E. \& Swan, B. (1987). Dietary conditions influencing relative zinc availability from foods to the rat and correlations with in vitro measurements. Journal of Nutrition 117, 1913-1923.

Irving, G. C. \& Cosgrove, D. J. (1974). Inositol phosphate phosphatases of microbial origin. Some properties of the partially purified phosphatases of Aspergillus ficuum NRRL 3135. Australian Journal of Biological Sciences 27, 361-368. 
Ketaren, P. P., Batterham, E. S., Dettman, E. B. \& Farrell, D. J. (1993). Phosphorus studies in pigs. 3. Effect of phytase supplementation on the digestibility and availability of phosphorus in soya-bean meal for grower pigs. British Journal of Nutrition 70, 289-311.

Lease, J. G. (1967). Availability to the chick of zinc-phytate complexes isolated from oil seed meals by an in vitro digestion method. Journal of Nutrition 93, 523-532.

Lei, X., Ku, P. K., Miller, E. R., Ullrey, D. E. \& Yokoyama, M. T. (1993). Supplemental microbial phytase improves bioavailability of dietary zinc to weanling pigs. Journal of Nutrition 123, 1117-1123.

Lowry, O. H. \& Lopez, J. A. (1946). The determination of inorganic phosphate in the presence of labile phosphate esters. Journal of Biological Chemistry 162, 421-428.

Miller, D. D., Schricker, B. R., Rasmussen, R. R. \& Van Campen, D. (1981). An in vitro method for estimation of iron availability from meals. American Journal of Clinical Nutrition 34, 2248-2256.

Miller, G. L. (1959). Use of dinitrosalicylic acid reagent for determination of reducing sugars. Analytical Chemistry 31, 426-428.

Mohammed, A., Gibney, M. J. \& Taylor, T. G. (1991). The effects of dietary levels of inorganic phosphorus, calcium and cholecalciferol on the digestibility of phytate-P by the chick. British Journal of Nutrition 66 , $251-259$.

National Research Council (1984). Nutrient Requirement of Poultry, 8th ed. Washington DC: National Academy Press.

Nelson, T. S., Shieh, T. R., Wodzinski, R. J. \& Ware, J. H. (1971). Effect of supplemental phytase on the utilization of phytate phosphorus by chicks. Journal of Nutrition 101, 1289-1294.

Ravindran, V., Denbow, D. M., Kornegay, E. T., Self, B. B. \& van Hulet, R. M. (1993). Supplemental phytase improves availability of phosphorus in soybean meal for turkey poults. Poultry Science 72, Suppl. 1, 73 Abstr.

Reddy, N. R., Pierson, M. D., Sathe, S. K. \& Salunkhe, D. K. (1989). Phytates in Cereals and Legumes. Boca Raton: CRC Press.

Ritter, M. A., Morr, C. V.\& Thomas, R. L. (1987). In vitro digestibility of phytate-reduced and phenolics-reduced soy protein isolates. Journal of Food Science $\mathbf{5 2}, 325-327,341$.

Saio, K., Koyama, E. \& Watanabe, T. (1968). Protein-calcium-phytic acid relationship in soybean. III. Effect of phytic acid on coagulative reaction in tofu-making. Agricultural and Biological Chemistry 32, 448-452.

Sanders, A. M., Edwards, H. M. Jr \& Rowland, G. N. III (1992). Calcium and phosphorus requirements of the very young turkey as determined by response surface analysis. British Journal of Nutrition 67, 421-435.

Schricker, B. R., Miller, D. D., Rasmussen, R. R. \& Van Campen, D. (1981). A comparison of in vivo and in vitro methods for determining availability of iron from meals. American Journal of Clinical Nutrition 34, 2257-2263.

Simons, P. C. M., Versteegh, H. A. J., Jongbloed, A. W., Kemme, P. A., Slump, P., Bos, K. D., Wolters, M. G. E., Beudeker, R. F. \& Verschoor, G. J. (1990). Improvement of phosphorus availability by microbial phytase in broilers and pigs. British Journal of Nutrition 64, 525-540.

Statistical Analysis Systems (1985). SAS User's Guide: Statistics. Cary, NC: SAS Institute Inc.

Vandepopuliere, J. M., Ammerman, C. B. \& Harms, R. H. (1961). The relationship of calcium-phosphorus ratios to the utilization of plant and inorganic phosphorus by the chick. Poultry Science 40, 951-957.

Vogt, H. (1992). Einsatz von Phytase im Broilermastfutter mit unterschiedenem Phosphorgehalt: 2 Versuch (Effect of supplemental phytase to broiler rations different in phosphorus content. 2nd trial). Archiv für Geflügelkunde 56, 222-226.

von Schöner, F. J., Hoppe, P. P., Schwarz, G. \& Wiesche, H. (1993). Vergleich von mikrobieller Phytase und anorganischen Phosphat bei Masthahnenküken: Wirkungen auf die Mastleistungen und die Mineralstoffretention bei variierter Calcium-Versorgung (Comparison of microbial phytase and inorganic phosphate in male chickens: the influence on performance data, mineral retention and dietary calcium). Journal of Animal Physiology and Animal Nutrition 69, 235-244.

Wolters, M. G. E., Schreuder, H. A. W., van den Heuvel, G., Van Lonkhuijsen, H. J., Hermus, R. J. J. \& Voragen, A. G. J. (1993). A continuous in vitro method for estimation of the bioavailability of minerals and trace elements in foods: application to breads varying in phytic acid content. British Journal of Nutrition 69 , 849-861.

Yatsu, L. Y. \& Jacks, T. J. (1968). Association of lysosomal activity with aleurone grains in plant seeds. Archives of Biochemistry and Biophysics 124, 466-471.

Żyła, K. (1993). The role of acid phosphatase activity during enzymic dephosphorylation of phytates by Aspergillus niger phytase. World Journal of Microbiology and Biotechnology 9, 117-119.

Żyła, K. \& Koreleski, J. (1993). In-vitro and in-vivo dephosphorylation of rapeseed meal by means of phytatedegrading enzymes derived from Aspergillus niger. Journal of the Science of Food and Agriculture 61, 1-6.

Żyła, K., Koreleski, J. \& Kujawski, M. (1989). Dephosphorylation of phytate compounds by means of acid phosphatase from Aspergillus niger. Journal of the Science of Food and Agriculture 49, 315-324. 